\title{
Development of a tool module for external intermittent grinding with the activation of the cutting fluid
}

\author{
A. Fesenko' ${ }^{1}$ F. Yevsiukova ${ }^{1} \cdot$ O. Naboka ${ }^{1}$
}

Received: 21 July 2021 / Accepted: 25 October 2021

\begin{abstract}
An instrumental module for external circular grinding has been developed, using methods of intermittent processing with replaceable abrasive bars with a combined supply of coolant through the pores of the bars and through the channels between them, with its activation in special cavitation nozzles.

The goal of this study is to develop a method for circular external inter-mittent grinding and a tool module that ensures stable operation of the wheel and efficient supply of cutting fluid to the cutting zone.

The tool module of the assembling grinding wheel has been developed, which provides the effect of intermittent grinding with the supply of cutting fluid through the abrasive bars and the gap between them.
\end{abstract}

Keywords: tool module, intermittent grinding, hydrodynamic cavitation, assembling grinding wheel, cutting fluid, mathematical model, abrasive sticks, machining operations, cylindrical grinder, control systems, adaptive control.

\section{Introduction}

The quality of the surface layer of machine parts that determine their performance characteristics in most cases is formed during grinding. This process is characterized by high thermal stress and a high probability of occurrence of defects in the surface layers of the ground parts in the form of burns and microcracks, which reduce their operational properties. One of the ways to reduce the thermal stress of the grinding process and improve the quality of the ground parts is the use of rational processing schemes and the use of effective compositions of cutting fluids, their activation, and supply to the cutting zone. To implement these conditions, we have developed a tool module for circular external grinding, using intermittent processing methods, which supplies cutting fluid to the cutting zone, and its activation in cavitation nozzles.

\footnotetext{
A.V. Fesenko anfesenko73@gmail.com

${ }^{1}$ National Technical University "Kharkiv Polytechnic Institute". Kharkiv Ukraine
}

\section{Literature review}

During the cutting process, the cutting fluid provides a lubricating, cooling, washing, dispersing, and damping action. One of the important requirements for the cutting fluid is to reduce the heat stress of the cutting process, reduce power loads and reduce friction, which leads to an increase in the quality of the processed surface of the part while maintaining the specified processing accuracy and increasing the durability of the cutting tool. For this purpose, various methods of delivering cutting fluid to the contact surfaces and activating it in the cutting zone are used.

At present, the processes of grinding with wheels having an intermittent surface are becoming more and more widespread.

It is known that the process of intermittent grinding in comparison with continuous provides a decrease in the maximum temperature by about $30-40 \%$, which is confirmed by theoretical calculations performed in [1-4].

The analysis of these studies with intermittent grinding showed that in the phase of the absence of contact of the wheel with the treated surface, its cooling is mainly provided by the thermal conductivity of this surface. In this case, the high intensity of heat outflow from the surface to the part is due to a large temperature gradient after contact 
with the wheel in the direction normal to the surface to be treated. Additional heat outflow from the heated surface is provided by convective heat exchange with the environment (air or cutting fluid).

However, the cooling effect of the cutting fluid has an insufficient effect over the heat extraction in the phase of the absence of contact of the wheel with the part. This is due not only to a lower intensity of heat transfer by convective heat transfer compared to thermal conductivity but also to the fact that the penetration of the cutting fluid into the space between the protrusions of the discontinuous surface of the wheel is difficult. The flow of cutting fluid into space between the protrusions of the wheel is slowed by the flow of air carried away by the wheel rotating at high speed. To ensure an intensive supply of cutting fluid to the space between the cutting protrusions of the wheel, attempts are made to supply cutting fluid through the wheel. This is achieved, for example, by filling the cutting fluid through the body of the assembled abrasive segments of the wheel into the spaces between the protrusions.

Besides, an increase in efficiency is possible when the cutting fluid is fed directly into the contact area of the protrusion of the wheel with the part through the pores of the wheel.

In intermittent grinding, the contact of the wheel with the workpiece is periodically interrupted, which leads to a decrease in the thermal saturation of the surface layers of the processed material. This allows improving the quality of processing while increasing the grinding performance. Moreover, the effect of interrupting the contact of the wheel with the workpiece is in some cases higher than that of optimizing the conditions of conventional grinding [5].

Long term researches, as well as the practice of using cutting fluid during grinding, convincingly prove that the effect of cutting fluid is most pronounced only if it penetrates directly into the interaction zone of the newly formed surfaces on the workpiece, wheel, and chip [6].

Analysis of the mechanisms of the lubricating, wetting and penetrating, cooling, washing, cutting, and plasticizing action of the cutting fluid, allows us to conclude that to increase the efficiency of the cutting fluid, it is necessary to increase its pressure and flow rate in the contact zones of the abrasive grains and the metal of the workpiece.

Under the influence of high temperatures and pressures in the cutting zone, there is an adhesive setting of the abrasive with the processed material, mutual diffusion of chemical elements, an increase in the friction work of the bundle and abrasive grains from the processed workpiece and, as a result, softening and destruction of abrasive grains, as well as the formation of a surface layer of the part with unfavorable performance characteristics. An important point to ensure the efficiency of the cutting process is the activation of the cutting fluid.

A simulation was performed of the temperature in the cutting zone during round external intermittent grinding, taking into account the supply of cutting fluid when it is actively ingested or absent between the abrasive bars.

Figure 1 shows graphs comparing the grinding process using continuous and intermittent cutting. And also without the use of cooling, as well as with water-based liquid pressure jet cooling.

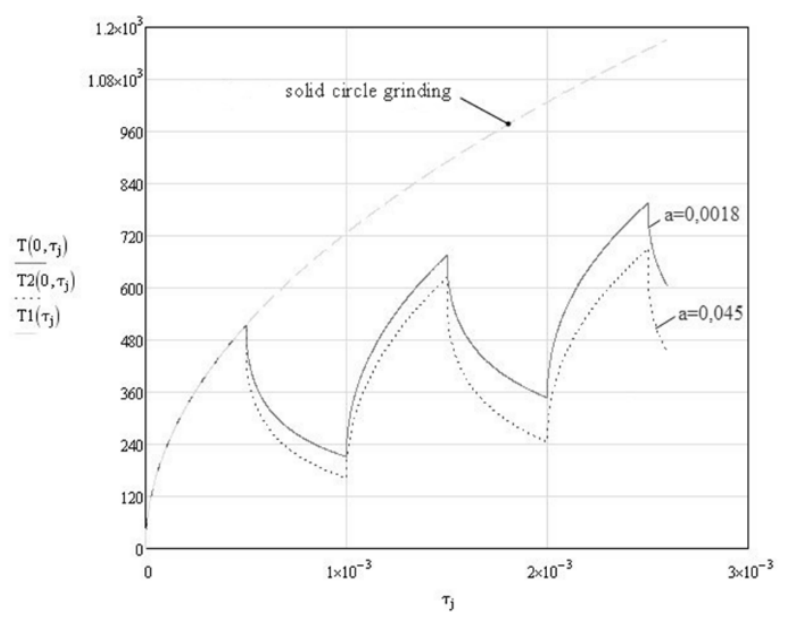

Fig. 1. Comparison of the heating temperature of the workpiece surface

The results of the computer experiment showed that under normal conditions, the cooling effect of the cutting fluid allows a slight (up to about $10 \%$ ) decrease in the maximum temperature during intermittent circular external grinding. By intensifying the cutting fluid supply through the wheel or the body of the assembling wheel, it is possible to predict the possibility of reducing the maximum temperature of the ground surface both due to the cooling effect of the cutting fluid, and due to its complex physicochemical effects.

In the works of E.S. Kiselev [8], to intensify the processes occurring in the cutting zone, the application of ultrasonic vibrations is used when the cutting fluid is fed through the nozzles installed at the ends of the grinding wheel. This changes the mechanism of penetration of the cutting fluid into the grinding and straightening zones: the liquid is ejected from the pores of the wheel directly into the zone of its contact with the workpiece. At the same time, it is noted that the functional actions of the cutting fluid usually are enhanced and have a significant impact on the performance and quality of the surface layer of the processed parts.

It is important that the cutting fluid cavitation in the cutting zone can radically change the conditions for forming new surfaces. The author claims that the superimposition of vibrations accelerates the movement of cutting fluid through the network of capillary channels to the zones of contact interaction of the tool with the workpiece material. Acoustic spraying of cutting fluid using the energy of an ultrasonic field allows you to create air-liquid aerosols, the size of liquid droplets in which are commensurate with the 
size of the cross-sections formed during the cutting of capillaries.

The process of intermittent grinding is associated with the occurrence of vibrations that is associated with the impact on the part of the protrusions of the grinding wheel.

In the works of several authors, methods of analytical solution of problems that determine the area of stable operation of the wheel are proposed. However, there is no quantitative analysis of the magnitude of the resulting fluctuations in the grinding depth as a result of the variable stiffness of the contact of the wheel with the treated surface.

Such an analysis is of great practical importance since the fluctuations of the system significantly affect the roughness of the treated surface. It is needed to perform an analysis and find solutions for the selected processing scheme. At the same time, in each specific usage case of intermittent grinding, the fluctuation amplitudes will be different due to the changing rigidity of the machine system.

Considering the above provisions, it is advisable to use a scheme that combines an intermittent grinding method and an effective cutting fluid supply with its activation.

\section{The goal of this study}

Is to develop a method for circular external intermittent grinding and a tool module that ensures stable operation of the wheel and efficient supply of cutting fluid to the cutting zone, for this purpose, a special tool module with replaceable abrasive bars has been created, through the pores of which the cutting fluid enters the cutting zone. Through separate channels, the cutting fluid is fed between the bars, providing cooling of the part. Through separate channels, the cutting fluid is fed between the bars, providing cooling of the part. All coolant supply channels are equipped with nozzles that use flow cavitators to activate the coolant.

\section{Methods for achieving the goal}

The proposed system uses the principle of intermittent grinding with the supply of cutting fluid through the radial channels of the cassette of the assembling grinding wheel [9]. The cutting fluid supply is carried out in the gaps between the bars and through the pores of the abrasive bars. At the outlet of the channels, nozzles are installed that ensure the activation of the coolant due to hydrodynamic cavitation.

To calculate the parameters of the grinding module, a special program for determining the geometric parameters of the tool was developed. The scheme for the calculation is shown in Figure 3.

When working with this program, you can change the input parameters and receive changes of other dimensions associated with the module whose parameters were changed.

An example of the calculation is shown in Figure 4.



Fig. 2. Supplying of cutting fluid through the channels of the grinding wheel

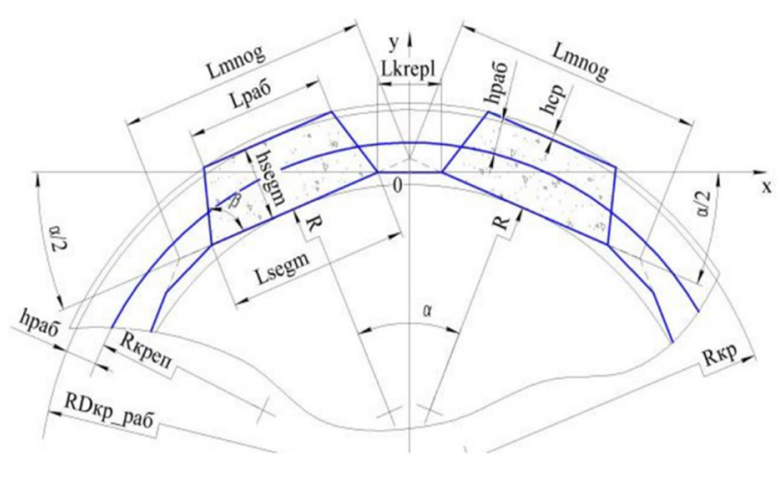

Fig. 3. Design scheme

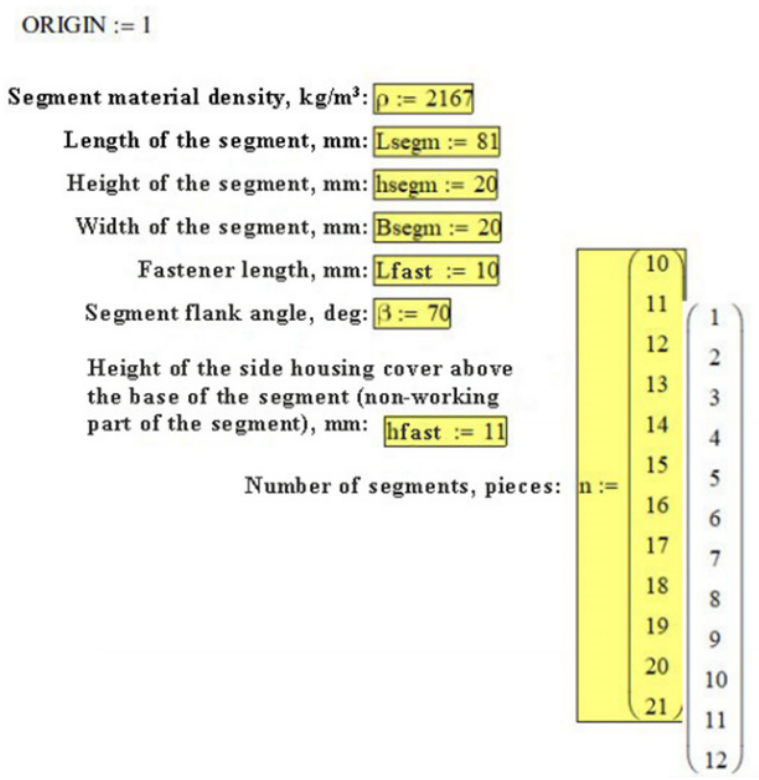

Fig. 4. Examle of calculating the parameters of the bar

When analyzing the dynamics of grinding, a rigid scheme of circular external grinding was considered, in 
which the cutting depth is set, and the derivatives are the forces and deformations in the technological system.

With a rigid grinding scheme, the wheel is fed to a certain depth $h_{i n}$ by the feed mechanism. Taking into account the elastic deformations of the machine under the action of the radial component of the cutting force $P_{y}$, the inertia of the moving masses of the machine, and the damping force, the actual grinding depth $h_{F}$ will differ by the amount of displacement of the wheel and the workpiece relative to each other.

The functional scheme of the intermittent grinding process in a closed technological system is determined depending on the adopted discrete machine model. Since these studies consider the change in the grinding depth with a high-frequency impact of the intermittent surface of the wheel, we can narrow to a two-mass machine model consisting of the masses of $m_{1}$ the workpiece and $m_{2}$ the wheel on the spindle. The mass of the grinding implement is conditionally assumed to be infinite, i.e. we believe that it will not react with radial movements to the force effects of an intermittent wheel due to its high inertia.

The input signal to the system is the grinding depth $h_{i n}$, which takes some actual value $h_{F}$, when the surface of the workpiece comes into contact with the protrusion, and zero - when the depression approaches. The radial component of the cutting force $P_{y}$ that occurs during grinding leads to deformations of the grinding wheel $x_{2}$ and workpiece $x_{1}$ systems. The total deformation in the contact area of the wheel and the workpiece $x_{3}$ leads to a change in the actual grinding depth.

Taking the direction of the coordinates $x_{1}$ and $x_{2}$ in opposite directions, leading to a decrease in the grinding depth, we get that the sum $x_{3}=x_{1}+x_{2}$ will be the total change in the grinding depth due to the displacement of the wheel and the workpiece. By subtracting this offset, $x_{3}$ from $h_{i n}$, we get the actual grinding depth $h_{F}$, which determines the value $P_{y}$.

The patterns described above can be represented in the form of a functional scheme of intermittent grinding (Fig. 5).

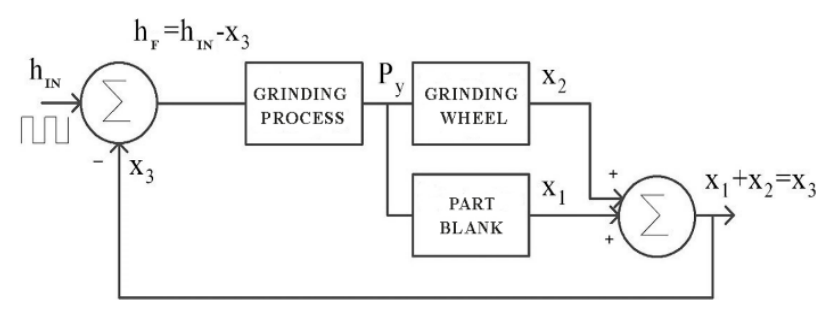

Fig. 5. Functional diagram of the intermittent grinding process
A characteristic feature of intermittent grinding is that as the wheel wears out, its macro profile self-forms. On the protrusions, frontal surfaces are formed, located at a certain angle of attack to the cutting plane [7].

In this study, we use a simplification, which comes down to the fact that the input signal does not take into account the wear on the front surface of the protrusions. Neither does it take into account the increase in the grinding depth when the front edge of the protrusion contacts with the workpiece and the decrease when the rear edge of the protrusion stops to contact.

During the grinding process, depending on the grinding depth, the radial component $P_{y}$ of the grinding force occurs. According to [10] $P_{y}$ is calculated by the following empirical formula:

$$
P_{y}=2,5 \cdot C_{p} \cdot V_{w}^{x} \cdot h^{y} \cdot S^{z} \cdot V_{r}^{\alpha} \cdot B^{\beta},
$$

where $V_{w}$ - the speed of rotation of the workpiece, $\mathrm{m} / \mathrm{s} ; h-$ depth, mm; $S$ - feed, $\mathrm{m} / \mathrm{min} ; V_{r}$ - the speed of rotation of the wheel, $\mathrm{m} / \mathrm{s} ; B$ - the height of the circle, $\mathrm{mm}$.

The mathematical model of the input signal in the VisSim package with the source data is shown in Figure 6.

Linearizing the dependence (1) by decomposing it into a Taylor series and omitting higher-order terms

$$
P_{y} \approx\left(P_{y}\right)_{0}+\left(\frac{\partial P_{y}}{\partial h}\right)_{0} \cdot \Delta h
$$

Where $\left(P_{y}\right)_{0}$ - is the value $P_{y}$ under the conditions of grinding in the equilibrium;

$\left(\frac{\partial P_{y}}{\partial h}\right)_{0}$ - the derivative $P_{y}$ of $h$ in the equilibrium.

Substitute $P_{y}$ from (1) and get:

$$
\begin{aligned}
\Delta P_{y}=P_{y}- & \left(P_{y}\right)_{0}=2,5 \cdot C_{p} \cdot V_{w}^{x} \cdot y \cdot h^{y-1} \cdot S^{z} \times \\
& \times V_{r}^{\alpha} \cdot B^{\beta} \cdot \Delta h=C \cdot \Delta h
\end{aligned}
$$

where $C=2,5 \cdot C_{p} \cdot V_{w}^{x} \cdot y \cdot h^{y-1} \cdot S^{z} \cdot V_{r}^{\alpha} \cdot B^{\beta}$

The value $C-$ is the coefficient of proportionality between the grinding depth and the radial component of the cutting force. Dimension of $C, \mathrm{H} / \mathrm{mm}$.

Similar to the rigidity of an elastic system with the same dimension, the coefficient $C$ - is called the rigidity of the grinding process or the rigidity of the contact of the wheel with the treated surface.

The elastic system of the circular grinding machine is a parallel connection of the elastic systems of the grinding wheel and the workpiece. The equation describing the movement of the grinding wheel in the radial direction, i.e., the coordinate $x_{2}$ is the equality of the forces acting on the circle in the radial direction. 


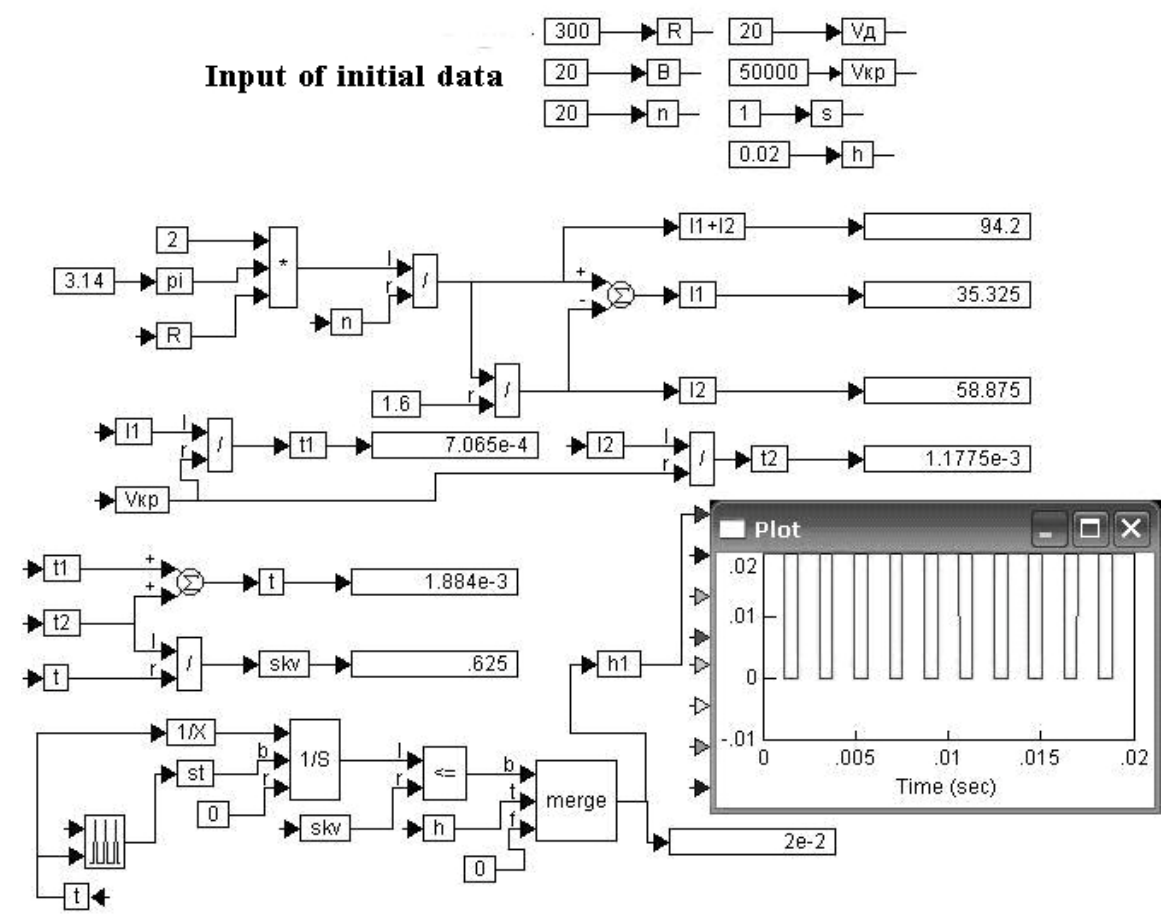

Fig. 6. Input signal simulation

If the positive direction of the coordinate $x_{2}$ is directed from the workpiece to the wheel, then the cutting force $P_{y}$ will be negative, and the other forces of inertia $m_{2} \cdot \ddot{x}_{2}$, damping $\lambda_{2} \cdot \dot{x}_{2}$ and elastic connection of the wheel with the spindle head $c_{2} \cdot x_{2}$ must be negative, i.e. in the opposite direction of the axis $x_{2}$ :

$$
m_{2} \cdot \ddot{x}_{2}+\lambda_{2} \cdot x_{2}+c_{2} \cdot x_{2}=P_{y}
$$

Similarly, can be obtained the differential equation of the movement of the workpiece in the radial direction, directing the coordinates of such movement $x_{1}$ from the wheel to the workpiece:

$$
m_{1} \cdot \ddot{x}_{4}+\lambda_{1} \cdot x_{1}+c_{1} \cdot x_{1}=P_{y}
$$

The solution of equations (3) and (4) in the VisSim package is performed by the method of reducing the derivative. The mathematical model of the solution is shown in Figure 7.

Deviation of the grinding depth $x_{3}$ due to the movement of the wheel $x_{2}$ and the workpiece $x_{1}$ under the action of force $P_{y}$ :

$$
x_{3}=x_{1}+x_{2}
$$

This deviation $x_{3}$ is subtracted from $h_{i n}$ and the actual grinding depth $h_{F}$ multiplied by the coefficient $C$ is converted to the force $P_{y}$.

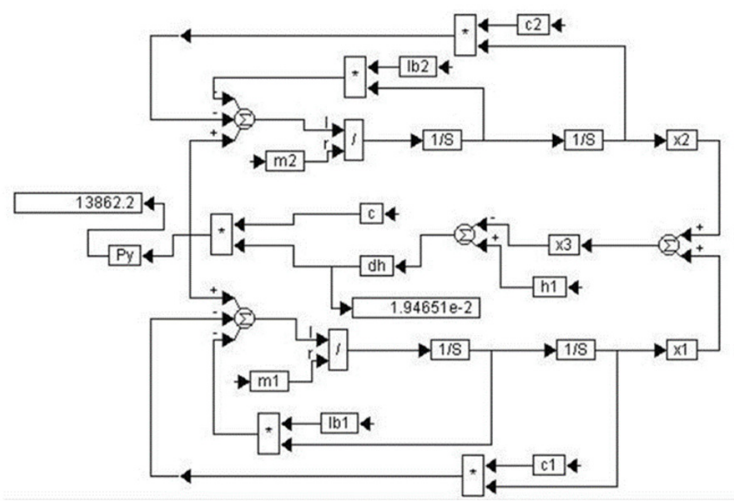

Fig. 7. Mathematical model

The calculations of the intermittent grinding process in a closed technological system are performed using the selected mathematical model and with displaying of the signals $x_{1}, x_{2}, x_{3}$ and $h_{F}$ on the Plot plotter (Figure 8).

The developed mathematical model of intermittent grinding in a closed technological system allows to analyze the design features of the wheel and choose rational cutting modes;

The use of this methodology allows to determine the magnitude of the amplitude of the actual depth of cut for specific processing conditions and select the parameters of the wheel. 


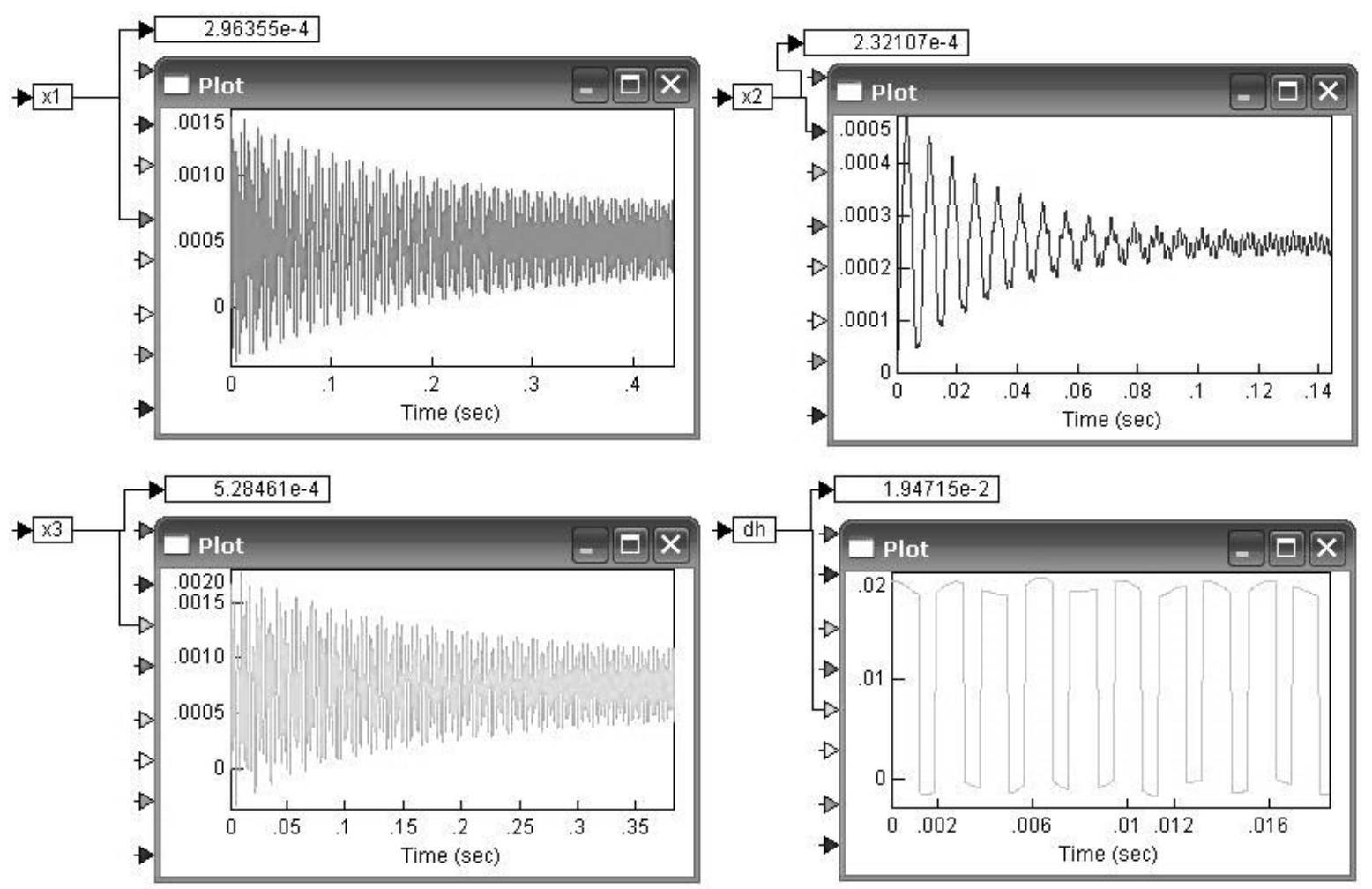

Fig. 8. Simulation results

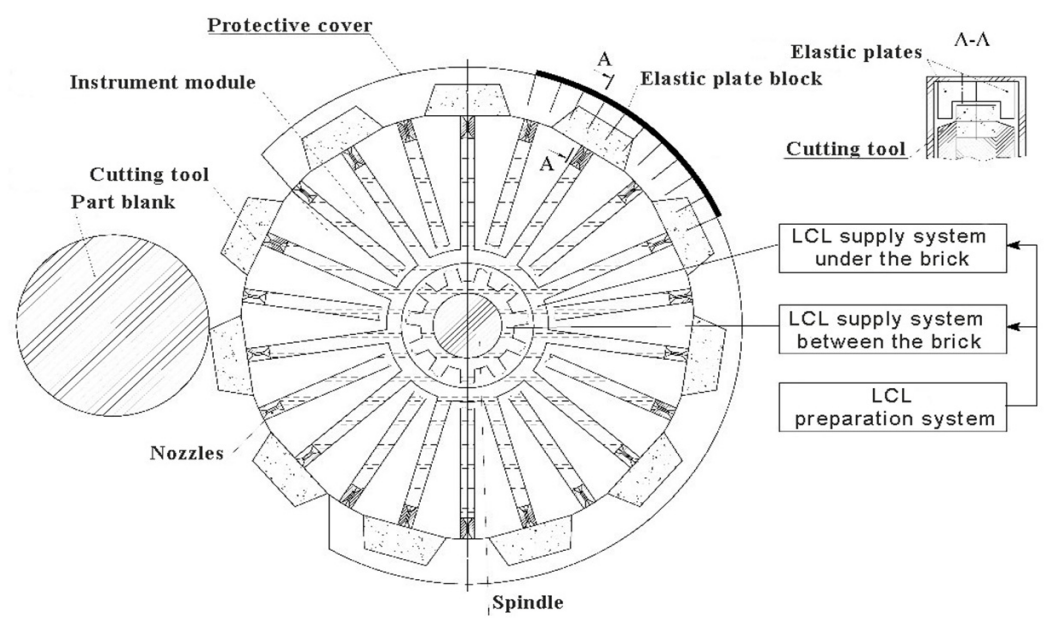

Fig. 9. Module with cooling and cutting fluid activation elements

For effective cooling of the grinding zone, the cutting fluid is supplied both through the bars and in the gaps between the bars. At the same time, nozzles are installed at the outlet of the channels to create cavitation in the flow.

The threshold values of the flow intensity at which cavitation occurs are very specific for grinding. Therefore, to determine the minimum required power in real grinding conditions, appropriate studies were conducted [16].

The increase in the velocity of the cutting fluid movement through the pore space of the wheel and the corresponding increase in its flow rate through the processed area is the result of the action of shock waves from the closing cavitation cavities localized in the cross-section of the pore channels. Optimization of the design parameters of the nozzles, the hydrodynamic parameters of the flow, the vibration frequency spectrum, and the range of sound pressure amplitudes should ensure effective cavitation of the liquid.

It follows from the above that in order to improve the productivity and quality of grinding, along with other methods, it is necessary to implement a comprehensive approach to the use of cutting fluid, including the choice of a 
rational composition and ensuring its effective use during grinding. This allows you to reduce the power loads and heat stress of the process.

The task may be solved with the help of a tool module (Fig. 9), which includes a body mounted on the spindle head of the machine, a assembling grinding wheel mounted on the spindle, two separate systems for supplying cutting fluid under the abrasive bars and in the gap between the bars, as well as a system with elastic elements for cleaning the grinding wheel. This module can be installed on various circular grinding machines and used for processing any materials and alloys.

The assembling grinding wheel (Figure 10) consists of a disk (cassette) 1 with channels 2 and 3 or supplying cutting fluid, mounted on the spindle of machine 4 and fixed to it using a bolt 5 [9]. On the edge of the disc, the abrasive segments 7 are fixated with the help of pressure elements 6 . The pressure elements 6 contain holes with cavitators fixed in them 8 . Cavitators 9 are installed under the abrasive segments in channels 3 . The pressure elements 6 are fixated with the help of the left 10 and right 11 covers of the grinding wheel. For balancing the grinding wheel in the assembled form, weights 12 are provided.

The assembling wheel is located in a body and is closed by the left 13 and right 14 covers of the protective casing. The left cover is fixated with screws 15 on the flange 16 of the grinding head. The use of a replaceable landing sleeve allows the installation of the body on machines that have landing elements of a similar design.

On the inner part of the protective casing, elastic petals 17 are fixated using a ring 18 and screws 19 and 20. The cutting fluid inlet bushings 24 and 25 are attached to the left cover of the protective casing through the glass 21 with the help of bolts 22 and 23. Insulation of the cutting fluid supply channels is performed using cuffs 30 and 31, installed in cups 21 and 27, respectively.

The cutting fluid supply to the cutting zone is carried out through two separate systems of channels, one of which provides the cutting fluid supply to the abrasive segments, and the second-between them.

To the cavity between the abrasive bars, the cutting fluid is fed through sleeve 25 . The sleeve with the impeller 26 provides preliminary acceleration of the emulsion. After that, the cutting fluid enters channel 2 of disk 1, where it is additionally accelerated due to the kinetic energy during the rotation of the grinding wheel and is directed to its edge between the abrasive segments 7 . Herewith, nozzles 8 are installed at the outlets from the channels which, due to the cavitation effect, provide its fine mixing, intensification of chemical and physical processes occurring in the cutting fluid and the cutting zone. Passing through the cavitation section, the cutting fluid enters the space between the segments before contacting it with the workpiece.

Under the abrasive segment, the cutting fluid supply is performed as follows. Through the inlet sleeve 24, the liquid enters sleeve 27 . Then, through the holes in cover 30 and gasket 31 , it enters channel 3 of disk 1, where it is additionally accelerated by kinetic energy when the grinding wheel rotates and is directed to its edge under the abrasive segment 7 . Herewith, nozzles 9 are installed at the outlet of the channels, which ensure the activation of the cutting fluid in the flow. The cutting fluid enters the working surface of the segment through the pores in the abrasive material.

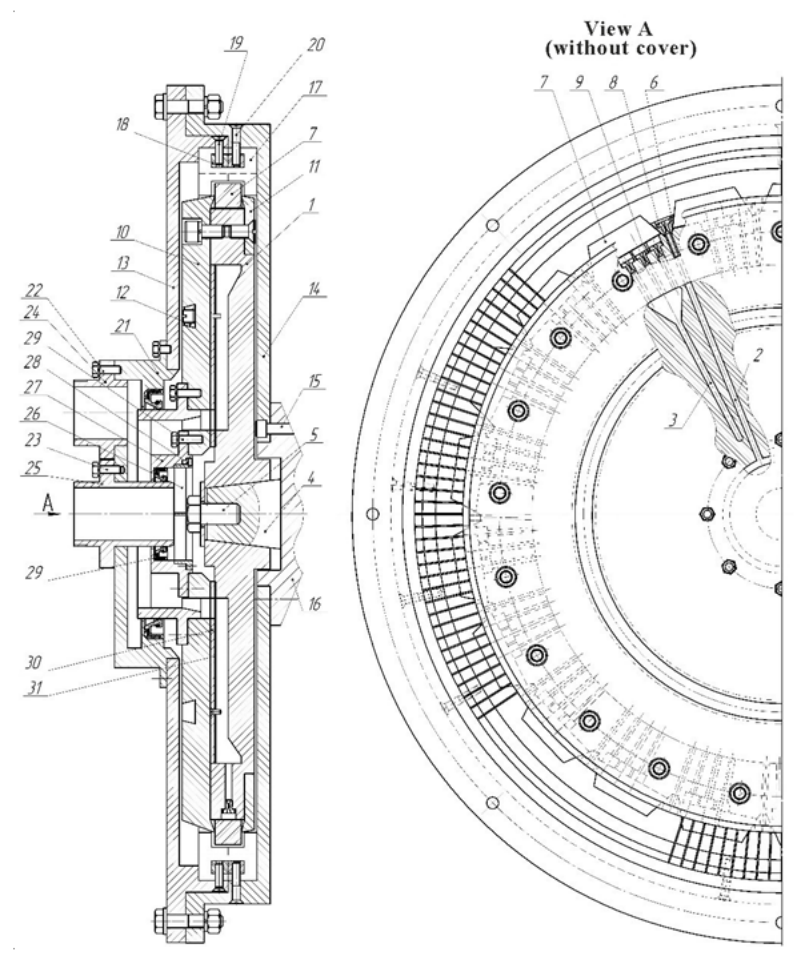

Fig. 10. Assembling grinding wheel module

An add-on to the SolidWorks 2009 COSMOS software was used to test the strength of the segments. This addition allows you to simulate the load on the segment of forces that occur during the grinding process.

During the simulation, the conditions for fixing the segment in the body with inserts were taken into account. The coordinates of the anchoring points and the places of the impact of forces on the bars were set, as shown in Figure 11.



Fig. 11. Placement of fixators 




Fig. 12. Simulation of the state of the replacement bar

As a result of the simulation, diagrams of stresses, displacements, deformations, and the safety margin were obtained. Figure 12 shows the simulation results.

It was found that for this design, the maximum speed of rotation is $135 \mathrm{~m} / \mathrm{s}$. at this speed, a segment break may occur.

Figure 13 shows the body of the assembling wheel 1 with the coolant supply channels between the bars 2 and under. bars 3 .

To clean the working surface, elastic elements 17 are installed in covers 13 and 14, which, under the influence of the flow, make mechanical vibrations that create the effect of acoustic cavitation of the cutting fluid.

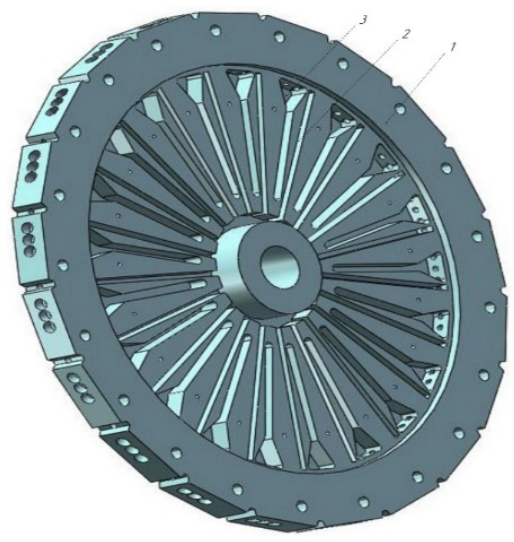

Fig. 13. Assembling wheel channels

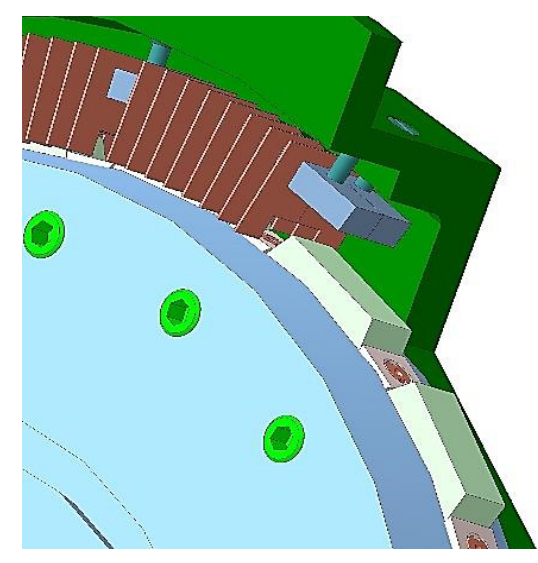

Fig. 14. Installment of the wheel cleaning petals

The combined cutting fluid supply system used in the module ensures that it is delivered to the working surface of the abrasive segments. This ensures the process of fine mixing of the cutting fluid, intensifies the chemical and physical processes occurring in the cutting fluid and the cutting zone, actively cleans the surface of the abrasive segment from salting, increases the cooling, lubricating, wetting, and other effects, which generally leads to an increase in productivity, processing quality and durability of the cutting tool [13].

Also, the circles of this design allow, if necessary, to adjust the cutting fluid flow through the channels, disconnect them, connect them separately, connect both without stopping the processing process. The pumps installed in each of the channels allow, in addition to the centrifugal effects, the use of cutting fluid flow control in terms of flow 
rate and pressure. Figure 15 shows the installation of cavitators in the body of the assembling wheel.

Figure 16 shows a general view of the assembling grinding wheel module.

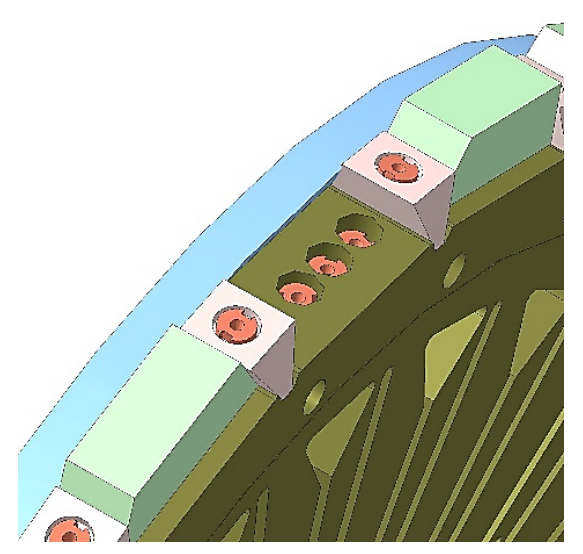

Fig. 15. Installation of cavitators in the assembling wheel body



Fig. 16. Installment of the elements in the cassette
The versatility of the proposed design lies in the fact that the replaceable bushings on the spindle and body allow you to install this module on several similar grinding machines.

This design allows you to significantly improve the dynamic performance of the machine. The cassette is subjected to careful static and dynamic balancing before the abrasive bars are installed. After installing the bars, additional balancing is performed with the help of weights installed in a circular groove. Due to the small volume and weight of the abrasive bars, the fluctuations caused by the unevenness of the abrasive material, its different densities, and wear are insignificant.

In production conditions, two (or more) cassettes are used. While one assembly wheel is on the machine, the operator reloads the second cassette.

The cassette design allows you to adjust the cutting fluid supply to the cutting area and in the gap between the bars, which can be used to rationalize the cutting fluid supply in the cycle (by changing pressures and volumes), as well as flexibly used in automated and adaptive systems, for example, when tracking changes in the cutting coefficient.

\section{Conclusions}

The tool module of the assembling grinding wheel has been developed, which provides the effect of intermittent grinding with the supply of cutting fluid through the abrasive bars and the gap between them. Its design makes it possible to improve the penetration of cutting fluid into the contact zone of the grinding wheel with the workpiece, which leads to a reduction in the heat intensity of the process and an improvement in the surface quality with an increase in processing productivity.

\section{References}

[1] A.V. Yakimov, Preryvistoe shlifovanie. Kiev, Ukraine: Vishcha shkola, 1986.

[2] A.V.Yakimov et al., Upravlenie protsessom shlifovaniya. Kiev, Ukraine: Tekhnika, 1983.

[3] A.V. Yakimov, Optimizatsiya protsessa shlifovaniya. Moscow, Russia: Mashinostroenie, 1975.

[4] F.V. Novikov and A.A. Yakimov, "K voprosu o sushchnosti preryvistogo shlifovaniya. Vysokie tekhnologii mashinostroeniya", Sbornik nauchnykh trudov NTU "KhPI”, Vol. 4, No. 1, 2001.

[5] M.M. Gasanov and E.V. Naboka, “Analiz vzaimodeistviya almaznogo kruga s obrabatyvaemym materialom”, Vesnik Natsional'nogo tekhnicheskogo universiteta, No. 16, pp. 45-48, 2003.

[6] Yu.A. Sizyi et al., "Podacha SOZh cherez radial'nye kanaly shlifoval'nogo kruga”, Visnik Natsional'nogo tekhnichnogo universitetu, Zbirnik naukovikh prats'. Tematichnii vipusk: Tekhnologiï v mashinobuduvanni, No. 25, pp. 25-32, 2010.

[7] A.V. Fesenko and Yu.N. Lyubimyi, "Povyshenie effektivnosti shlifovaniya pri gidrodinamicheskoi obrabotk SOZh", Visnik Natsional'nogo tekhnichnogo universitetu, Zbirnik naukovikh prats'. Tematichnii vipusk: Tekhnologï v mashinobuduvanni, No. 49, 2010.

[8] Yu.A. Sizyi, A.V. Fesenko, Yu.N. Lyubimyi, “Teplonapryazhennost' protsessa kruglogo preryvistogo shlifovaniya s okhlazhdeniem”, Visnik Natsional'nogo tekhnichnogo universitetu, Zbirnik naukovikh prats'. Tematichnii vipusk: Tekhnologiï v mashinobuduvanni, No. 40, pp. 94-103, 2010.

[9] E.S. Kiselev, Intensifikatsiya protsessov mekhanicheskoi obrabotki ispol'zovaniem energii ul'trazvukovogo polya, Ul'yanovsk, Russia: UlGTU, 2003. 
[10] A.V. Fesenko and Yu.M. Lyubimii, “Zbirnii shlifuval'nii krug”, Patent na korisnu model' No. 56635. Ukraïna, MPK (2011) V24D 5/00. No. u 2010 07045; opubl. 25.01.2011, Byul. No. 2.

[11] E.N. Maslov, Teoriya shlifovaniya materialov, Moscow, Russia: Mashinostroenie, 1974.

[12] Yu.A. Sizyi et al., "Matematicheskoe modelirovanie dinamiki preryvistogo shlifovaniya", Visnik Natsional'nogo tekhnichnogo universitetu, Zbirnik naukovikh prats'. Tematichnii vipusk: Tekhnologiï v mashinobuduvanni, No. 24, pp, 40-49, 2010.

[13] A.V. Fesenko and Yu.N. Lyubimyi, "Povyshenie effektivnosti shlifovaniya pri aktivatsii i ratsional'nom ispol'zovanii SOZh", Visnik Natsional'nogo tekhnichnogo universitetu, Zbirnik naukovikh prats'. Tematichnii vipusk: Tekhnologiï v mashinobuduvanni, No. 41, pp. 71-100, 2010.

[14] A.V. Fesenko and Yu.M. Lyubimii, "Pristrii dlya p1dvedennya mastil'no-okholodnzhuyuchoï ridini”, No. 56655 Ukraïna, MPK (2011) V24D 5/00, No. u 2010 07262, opubl. 25.01.2011, Byul. No. 2.

\section{Розробка інструментального модуля для зовнішнього періодичного шліфування}

\section{А. Фесенко, Ф. Євсюкова, О. Набока}

Анотація. Розроблено інструментальний модуль для зовнішнього кругового шліфування, щэо використовує методи переривчастої обробки зі змінними абразивними прутками з комбінованою подачею теплоносія через пори брусків $і$ через канали між ними з його активацією в спеціальних кавітаційних насадках.

Мета. Полягає в розробиі способу кругового зовнішнього переривчастого шліфування та інструментального модуля, щзо забезпечує стабільну роботу круга та ефективну подачу ріжучої рідини в зону різання.

Висновок. Розроблено інструментальний модуль монтажсного шліфувального круга, що забезпечує ефект переривчастого иліфування з подачею ріжучої рідини через абразивні бруски та зазор між ними. Його конструкиія дозволяє покращити проникнення ріжучої рідини в зону контакту шліфувального круга із заготовкою, що призводить до зниження теплоінтенсивності процесу та покращення якості поверхні при підвищенні продуктивності обробки.

Ключові слова: модуль інструменту, періодичне шліфування, гідродинамічна кавітація, складання шліфувального круга, ріжуча рідина, математична модель, абразивні палички, операції механічної обробки, ияліндрична шліфувальна машина, системи управління, адаптивне управління.

\section{Разработка инструментального модуля для внешнего прерывистого шлифования}

\section{А. Фесенко, Ф. Евсюкова, Е. Набока}

Аннотация. Разработан инструментальный модуль для наружного кругового шлифования, используюший методы прерывистой обработки сменными абразивными стержнями с комбинированной подачей СОЖ через поры стержней и по каналам между ними, с активачией его в специальных кавитационных соплах.

Цель. Состоит в разработке способа кругового наружного прерывистого шлифования и инструментального модуля, обеспечивающего стабильную работу круга и эффективную подачу режущей жидкости в зону резки.

Вывод. Разработан инструментальный модуль монтажного шлифовального круга, обеспечивающий эффект прерывистого илифования с подачей режущей жидкости через абразивные бруски и зазор между ними. Его конструкция позволяет улучшить проникновение режущей жидкости в зону контакта шлифовального круга с заготовкой, что приводит к снижению теплоинтенсивности процесса и улучшению качества поверхности при повышении производительности обработки.

Ключевые слова: инструментальный модуль, прерывистое шлифование, гидродинамическая кавитация, сборка шлифовального круга, смазочно-охлаждающая жидкость, математическая модель, абразивные стержни, операции обработки, изилиндрический шлифовальный станок, системы управления, адаптивное управление. 